\title{
Implementation lifelong learning: The Adult Learners Based Learning Needs
}

\author{
Wiwin Yulianingsih, Supriyono, Ach.Rasyad, Umi Dayati \\ Departement Non Formal Education \\ Malang State University \\ wiwin.yulianingsih@yahoo.co.id
}

\begin{abstract}
Adult education has the approach, scope and objectives as well as different strategies to education for children. Learners are adults in learning activities to choose, establish and develop the method chosen to achieve the desired learning outcomes. Selection, establishment and development of methods based on the conditions existing learning The adult learners as a lifelong learning process, adult has a self-concept, experience, learning orientation and readiness to learn. Learning need of adult have variation, such as: Learning needs relate to job duties. Learning needs associated with indulgence and recreation. Learning needs related to religious. Learning needs related to language skill and general knowledge. Learning needs related to domesticity. Learning needs relating to personal appearance. Learning needs related to knowledge about new event. Learning needs related to business in agriculture. Learning needs relating to services. Those classifications can adult learners wider of learning needs vary, presumably can be concluded that multiple purposes, multiple agents and multiple programs can be used as input in determining the course of study in a non-formal education to develop a variety of learning programs.
\end{abstract}

Keywords-Adult learner, learning need

\section{INTRODUCTION}

Lifelong learning is a part of educational process itself. Lifelong learning, a different individual to other individual, one community to another is different too. All of that can be seen from what learning needs of people, especially adult, as well as adult assumption, which is explained in Knowles that adult has a self-concept, experience, learning orientation and readiness to learn. Lifelong learning, community learning and knowledge society has a broad meaning.

However, at this writing more emphasis on the implementation of lifelong education especially adult learner who learns because according to his needs.

Lifelong learning process experienced on the human life which is realize or not, yet those process take place naturally and still continue, as opinion of Ivan Illich said that study not be insulated by space and time, because study can do anywhere and anytime. When information technology not as sophisticated as today, Ivan Illich already thinking Learning Webs (network learning). In this case that knowledge must be used to solve problems and add value to life. Whatever one's busy life and work, will always need to learn in every time, throughout his entire life.
Lifelong learning theory is stimulated by thoughts of theory human learning, which recognizes the lifelong nature in a person's learning activity. Learning does not stop when a person completes the formal or non-formal education but learned the process of interaction and relationship that lasts throughout a person's life in a particular social context until it ends in death. This means that learning is a process of transformation of one's own experience and will always occur when people interact with the wider social environment. Start from the family, community and school. Jean Jacques Rousseau said that man must learn to live a more decent, as at the moment we are born to take part of our citizenship rights, when it should be the starting point for the implementation of our duty, as a pedagogic that has the freedom to learn. Nature will teach how we should learn and behave as living creatures that have various advantages even nearly perfect. Nature is a good teacher as well as companion of mankind.

\section{CONTENTS STUDY AND DISCUSSION}

The concept of lifelong learning cannot be separated from the process of development of human civilization. Perspective learning from cradle to grave is widely known and promoted in many countries. As time goes by and the varied learning needs, concepts and forms of learning and education is increasingly becoming more widespread, synergies with the spirit and the need to learn continuously in various occasions [1].

Development of human potential lifelong learning recognizes that each individual has the potential to learn and also take some of the limitations contained in the individual potential. For it can make a quantum leap (Quantum Leaps) in achieving our human potential and we can certainly when we have an opportunity and an enjoyable experience. Furthermore, humans should have the potential to support or endorsement(supportive), continuously until an understanding (understanding) the level of one's understanding is often obtained from the study of knowledge applicative skills.

Quoting from opinion Kai Mien [2] In line with Tony Wagner research and research Berny Trilling Joint Fadel. Through a series of studies, Wagner (2008) found what he called the survival skills, including the ability to think critically and solve problems, ability to cooperate across cultures, dexterity and communication skills both oral and written, ability to find and analyze information, curiosity and the ability to imagine. Proposed the so-called 21 st century skills (21stcentury skills) is the ability to think critically and solve 
problems, communication ability to innovate media and technology skills that include information literacy, media literacy and ICT, as well as life and career skills that include flexibility and adaptive ability, initiative and the ability to direct themselves, social skills and cross-cultural interaction, productivity and responsible leadership

In the perspective of other mentioned that there are at least two purposes from lifelong learning including self-contained or self-learning namely (1). To adjust to the positive changes those are continually changing and evolving in all human life (2) to prepare themselves in order to achieve a better life in the future. Learning life gained more into education informal and non-formal education.

Lifelong learning is continuum of elements relevant process element is inter-related (interdependent), which is based on needs of individual in education throughout his life. Adults have the specific and diverse needs to support its activities. The following figure 1 on a lifelong learning process.

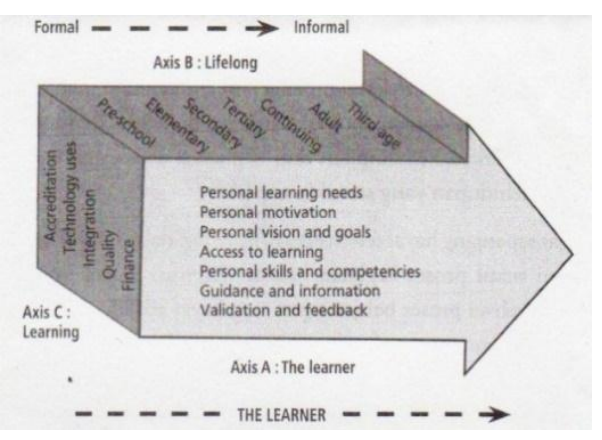

Fig. 1. Lifelong Learning Process [3]

Depicts a lifelong learning process that stretches from formal education, non -formal to informal. A- learner- axis is the values, skills and attributes of learning all the time as shown in the axis B. The axis B is a lifelong - level difference in knowledge and understanding, through formal learning system to informal learning systems. C -axis is learning a set of supporters of the system of lifelong learning in which learners adapt to the learning needs. The pictures show a lifelong learning process that takes place in the continuum.

Education as a process taking place throughout the life of the individual so that education can always help solve the problems faced by individuals in order to improve the quality of life in accordance with its objectives, therefore, [4] states: " Education is a Viewed as a continuing process guided by the over - riding goal of improving the quality of life." (education is seen as an ongoing process that is guided by the aim of improving the quality of life) including in this case is the ongoing implementation of non-formal education is needed by adult learners, with the aim of improving the quality of life.

Learning is no longer described into a place, building and time to gain knowledge (school) as well as apply knowledge (workplace, institution or office). Today's society is flooded with more information diverse, than they can handle. Lifelong learning is an important challenge to find the future of our society. Lifelong learning over adult education, training, education skills, this is the mindset of a habit for people to obtain the meaning of learning. Lifelong learning creates a challenge to understand, explore and support the critical dimensions that are new to education. Every person has learned in his life.

These approaches require new media and technologies to be supported adequately. Long life learning theory should investigate new frameworks for learning required by the major changes and rapid in education and employment. These changes are:

1) Increased prevalence of high-tech jobs need support to learn on the basis of the demands because it covers all that are not possible.

2) Changes are inevitable in an age unusual profession that requires lifelong learning and

3) Deepening differences in the opportunities offered to the educated and the uneducated.

Learning needs can be defined as a distance between the level of knowledge, skill, or attitude held at a time by the level of knowledge, skills and attitudes to be obtained or a person, group, organization, or community that can only be achieved through learning activities [5]. For example, a young man who expressed a desire to learn the art of the region in order to expand his knowledge of the types of art that spread in Indonesia. Here are the learning needs expressed by Johnstone and Rivera there are nine types of learning needs, are as follows:

1. Learning need related to job duties.

a. Increased professional skill to carry out the task.

b. Skills using advertisement and marketing techniques.

c. The skills to do the training and skills.

d. Skills to use working tools, etc.

2. Learning skills associated with indulgence and recreation.
a. Skills workout.
b. Skills use the music instruments.
c. Skills of painting and sculpturing.
d. Dancing skills.
e. Drawing and painting skills.
f. Staging skills, recreation and more.

3. The learning need related to religious
a. Increased knowledge of the religion professed and how his experience in daily life.
b. Knowledge and skills about ways to study and religious broadcasting.
c. Increased awareness and religious attitudes.

4. The need for learning associated with language skills and general knowledge.

a. Knowledge and foreign language skills.

b. Knowledge and understanding of history.

c. Knowledge and understanding of natural sciences and others.

5. The learning need related to domesticity.

a. Skills of fashion, culinary and housekeeping. 
b. Skill of increasing family income.

6. Learing needs related to appearance.

a. Skills of maintain physical fitness.

b. Make up skills.

7. Learning needs related to knowledge about new event.
a. Knowledge about event in abroad.
b. Knowledge about various political current.
c. Knowledge about other contemporary information.

8. Learning needs relating to the business of agriculture.
a. Skills of cultivate, select seeds and nurturing plants.
b. Skills of combat disease and pests.
c. Skills of process agricultural products and market.
d. Skills of raising livestocks and fish.
e. Fostering the skills of farming.

9. The need for learning related to services.
a. Driving skill.
b. Skills of transportation services.
c. Skills related to other services.

The classification above can be expanded according to the evolving needs and changes taking place in society. Mainly adults who have called for the immediate needs of learning can be applied in everyday life, in accordance with the role and social status. The classification can give you a wider of learning needs vary, presumably it can be said multiple purposes, multiple agent and multiple programs that can be used as input in determining the course of study in a nonformal education to develop a variety of learning programs, take continued and sustainable activities. It is a cornerstone associated with the development of adult learning needs-based.

As such learning takes place in the Village of English Pare, Kediri. This is phenomena that can be said only one in the world, precisely in Indonesia, East Java Province, Kediri District. Phenomena in the village of English Pare, students, adults who have busy and central role in social status or occupation, they flocked to follow courses in English, they are willing to reside temporarily in the area around the course, to follow the program that has been selected. According to data from the local education office and the results of field observations conducted by the authors for 3 times, there are 150 institutions known foreign language courses, primarily $90 \%$ are in English, the rest in Arabic, and Mandarin. The enthusiasm of the learners is adults who have a very high interest to follow an English course in Pare, Kediri. This is evident from the category of the course participants are high school graduates across the region in Indonesia, graduate or still a student level bachelor and magister or doctor even college students.

Meanwhile, among some of the courses observed, there is a cottage system implementation was done by the institute courses in Pare, Kediri, including BEC, Hello English, Feture Course, Genta Course. Active and creative learning strategy PACEF (Participation, Active, Creative, Effective and Fun). This can be described as a form of implementation of Lifelong Learning: learner adult based learning needs, they come in droves, far from various regions in Indonesia, with the intention of consciousness itself to come to the village of English Pare as their wishes, could English [6].

Carl Rogers stated that humans have a natural instinct and desire to become a better human being. Humanistic approach in education emphasizes the positive development of man, namely concentration on human potential to search and find capabilities they have, including interpersonal skills, social and personal development. Carl Rogers in his book titled The Freedom to Learn mention a number of basic humanistic principle, including:

1. Humans have ability to learn naturally.

2. Learn will effective when the subject matter was relevant to what is felt by students (learners).

3. Learning that involves a change in the students / learners tend to be seen as threatening and rejection.

4. Learning will meaningful if learning involves students / learners.

5. The process of teaching and learning activities will be smooth if students/ learners involved in the teaching process itself.

6. Self-confidence, independence and creativity are more easily achieved if the student is accustomed to introspection by way of criticizing himself.

The appeal of English language courses for adults in England Pare village that shows the needs of adult community learning related to improving the competence to find work, preparation for entering college level bachelor and magister or doctor, preparation and competition overseas scholarships included spare time after graduating from high school or equivalent and pass accelerando magister or doctor, or equivalent. The need to learn the English language in Pare included as part of the implementation of adult learning in terms of answering the needs of a more realistic, one needs to learn English to conditions or circumstances surrounding. So there is a common thread among adults learn learning needs. This is in accordance with the opinion by [7] That the types of adults there are five levels below, including the need to learn English. In stages Jenny said in the book Adult Learners: includes 1. Unconscious incompetence (adults does not realize and do not have the ability), 2. Conscious incompetence (realized and do not have the ability), 3. Conscious competence (awareness of his ability), 4. Unconscious competence (competence but did not realize),5. Thinking competence (competence think), so it appears the need to learn what else is needed. From the five stages of thinking adult would cause a person's learning needs. It can be said that adult learning was flipped focus learning teacher centered to student centered, from the academic to the idealistic pragmatism or real educational needs in the community. Because the needs of each individual learner are a perceived need.

While [8] needs and requirement in Romanian adult education and training system using modern methods. A modern and efficient adult training system brings, undoubtedly an added value on a human resource quality a professional staff body in institutions and companies, able to raise the performance level and satisfy citizens interest and needs. 
Another team building, benchmarking, coaching, and brainstorming.

\section{CON CLUSION}

Lifelong learning is part of the educational process itself. Lifelong learning, a different individual to other individual, one community to another is different too All that can be seen from what the learning needs of the community, especially adult. The classification can give you a wider of learning needs vary, presumably it can be said multiple purposes, multiple agents and multiple programs that can be used as input in determining the course of study in a non-formal education to develop a variety of learning programs, take continued and sustainable activities. It is a cornerstone associated with the development of adult learning -based needs. Adult learning is intended to improve the quality of personal life because dale lifelong learning process that every human being can acquire the knowledge, skills, moral values, attitudes and understanding functional.

\section{ACKNOWLEDGMENT}

The authors would like to thank the leadership department non formal education state universities of Surabaya and my promotor co promotor in the department of non-formal education state university of Malang.

\section{REFERENCES}

[1] Pramudia, Rahmat Joni. Belajar Sepanjang Hayat : Konsep, Kebijakan dan Aplikasi dalam Pendidikan Nonformal menuju Masyarakat Berpengetahuan. Bandung. EDUKASIA Press. 2013

[2] Samani, Muchlas. Mohon Maaf...Masih Compang-camping: Kumpulan Catatan Sebagai Rektor Universitas Negeri Surabaya, Jabatan 20102014. Surabaya. Unesa Inuversity Press. 2014.

[3] Longworth, Norman and Davies, W.Keith. Lifelong learning:learning.London:Kogan Page 2006.

[4] Dave RH (1976) Foundation of life long education, New York. Perganon Press

[5] Sudjana,H. Djuju. Pendidikan Luar Sekolah: Wawasan, Sejarah perkembangan, Filsafat, Teori Pendukung, Asas. (Bandung: Falah Production), 2001.

[6] Trinawati, Gina (2013). Penerapan Sistem Pembelajaraan Pondok Dalam Meningkatkan Penguasaan Materi dan Keberhasilan Alumni di Lembaga Kursus BEC (Basic English Course) Singgahan Pelem Pare Kabupaten Kediri.

[7] Rogers, Jenny, (2007) Adults Learning Fifth Edition. Open University

[8] Mihaela dimitrescu, Luiza Venera Sarbu, Ynonne Lacroix 1. Europen Trends for Adult Education in Lifelong Learning Strategi : Modern Methods and Romanian Skill in Training Management. 2015 ELSEVIER Procedia-Social and behavioral Science 1161-1169. 